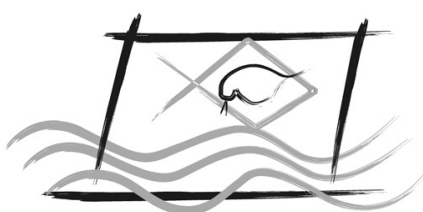

ECOTOX - BRASIL

\title{
Acute toxicity and sublethal effects of phenol on hematological parameters of channel catfish Ictalurus punctatus and pacu Piaractus mesopotamicus
}

\author{
F.D. De Moraes; J.S.L. De Figueiredo; P.A. Rossi; F.P. Venturini \& G. Moraes* \\ Federal University of São Carlos, Department of Genetics and Evolution, \\ Rod. Washington Luiz Km 235, Sao Carlos, CEP 13565-905, SP, Brazil
}

(Received January 07, 2015; Accept May 20, 2015)

\begin{abstract}
Phenol is an aromatic chemical commonly found in domestic and industrial effluents that represents a worldwide concern in toxicology. When it reaches aquatic environments, significant damage in fishes is observed. The first aim of this study was to investigate the acute toxicity levels of phenol in Ictalurus punctatus and Piaractus mesopotamicus. The second objective was to evaluate the hematological parameters of I. punctatus and P. mesopotamicus after 96 hours exposure to sublethal concentration of phenol $\left(10 \%\right.$ of 96 -hour $\left.\mathrm{LC}_{50}\right)$ and after post-exposure recovery period of 7 days. The main hypothesis of the study was that even sublethal phenol concentration could cause hematological alterations in fish. For 96-hour $\mathrm{LC}_{50}$ tests, both fish species were exposed to several phenol concentrations (in the range between 5 and $50 \mathrm{mg} \mathrm{L}^{-1}$ ) and the mortality were recorded after 24, 48, 72 and 96 hours. Phenol was notably more toxic to I. punctatus than P. mesopotamicus and the 96-hour $\mathrm{LC}_{50}$ values were 15.08 and $32.56 \mathrm{mg} \mathrm{L}^{-1}$, respectively. Sublethal exposure to phenol in P. mesopotamicus resulted in significant higher hematocrit level $(\mathrm{Ht})$, hemoglobin content $(\mathrm{Hb})$ and red blood cell count $(\mathrm{RBC})$ in comparison with control group. In $I$. punctatus, $\mathrm{Ht}, \mathrm{Hb}$ and $\mathrm{RBC}$ remained constant after 96-hour sublethal exposure. However, after the recovery period of 7 days a significant increase of RBC followed by reduction in mean corpuscular volume (MCV) and mean corpuscular hemoglobin $(\mathrm{MCH})$ were observed in I. punctatus. The sublethal responses to phenol revealed erythropoeisis in I. punctatus and respiratory distress in P. mesopotamicus. P. mesopotamicus presented excessive skin and gills mucus throughout the 96-hour $\mathrm{LC}_{50}$ tests. Acute toxicity tests and hematological responses after exposure to sublethal phenol concentration could be successfully used as a biomarker of stress in fish and may be applicable to investigate others toxic agents.
\end{abstract}

Key-words: bioassay, hematology, freshwater fish, $\mathrm{LC}_{50}$, xenobiotic.

\section{INTRODUCTION}

Aquatic environments are susceptible to phenol contamination from domestic and industrial effluents. Some phenol derivatives are formed during natural processes such as organic matter decomposition and vegetal synthesis (Michalowicz \& Duda, 2007). Pollutants can cause significant damage to fish health. Skin, gills, and gut are the first structures affected by phenol, thus they play an important role in the absorption of xenobiotics (Kleinow et al., 2008).
Phenol absorbed into the blood of fish in polluted water can spread to other parts of the body and cause many biological disturbances (Ravichandran \& Anantharaj, 1984; Saha et al., 1999). Although the maximum limit for the concentration of phenol in treated effluents $\left(0.5 \mathrm{mg} \mathrm{L}^{-1}\right)$ and freshwater $(0.003$ - $1 \mathrm{mg} \mathrm{L}^{-1}$ ) are becoming more stringent in Brazil (Brasil, 2005; Cetesb, 2014), phenol contamination in water basins is often from either industrial wastewaters or accidental phenol discharges. Phenol concentrations in Brazilian's class 2 freshwater are generally $20 \%$ higher than the limit allowed by the government (Cetesb, 2008). 
The mechanism of action of phenol is multifactorial (Roche \& Bogé, 2000). Chlorine-substituted phenols can cause polar narcosis and nitro-substituted phenols act as respiratory uncoupling agents (Loomis \& Lipmann, 1948; Lee et al., 2006). The toxic effects of phenol and its derivatives in several fish species have been reported, including hematological alterations (Roche \& Bogé, 2000), induction of genotoxicity (Bolognesi et al., 2006), carcinogenesis and mutagenesis (Tsutsui et al., 1997; Yin et al., 2006), endocrine disruption (Kumar \& Mukherjee, 1988), and metabolism imbalance (Hori et al., 2006). Therefore, evaluation of fish susceptibility to phenol is pivotal to preventing undesirable effects from chronic exposure.

The mortality test is the first approach to evaluate the environmental safety and toxicological degree of chemical substances (Rand et al., 1995). The relative chemical toxicity to aquatic organisms is determined by an acute test that estimates the lethal concentration of pollutant to $50 \%$ of a test population $\left(\mathrm{LC}_{50}\right)$ (Rand et al., 1995; Zagatto \& Bertoletti, 2006). Many endpoints of the phenol toxicity remain unknown for several fish species. Pacu Piaractus mesopotamicus (Holmberg 1887) and channel catfish Ictalurus punctatus (Rafinesque 1818) are neotropical and prominent commercial fish species in Brazil; however, no data are available on acute toxicity of phenol of these fish species. Hematological responses are useful for investigating sublethal effects of pollutants on fish health. For that reason, we have investigated the phenol lethal concentration (96-hour $\mathrm{LC}_{50}$ ) and the effects of sublethal concentrations of phenol on the hematological profile of $P$. mesopotamicus and I. punctatus.

\section{MATERIAL AND METHODS}

\section{Ethics}

The Ethic Committee for Animal Research of the Federal University of Sao Carlos approved the experimental conditions and procedures observed in this study (CEEA 039/2007).

\section{Phenol}

Phenol was purchased from Sigma-Aldrich and previously desiccated under vacuum with silica at room temperaturein the dark. The quantitative detection of phenol in the water samples was based on the color reaction of phenolic compounds with 4-aminoantipyrine in the presence of potassium ferrocyanide under alkaline conditions, which gives a prominent pink color (APHA, 1980). The reaction product was analyzed by UV/ Vis spectrophotometry (Beckman DU 520) at $500 \mathrm{~nm}$ against a reagent blank.

\section{Fish maintenance}

Fish samples, I. punctatus and P. mesopotamicus, were purchased from a local fish farm and acclimated for 10 days in a water flow-through system of $2000 \mathrm{~L}$ fiber tanks in the following environmental conditions: temperature $24-27{ }^{\circ} \mathrm{C}$, $\mathrm{pH}$ 7.1-7.2; $\mathrm{NH}_{3}-\mathrm{NH}_{4}^{+} 0.1-0.3 \mathrm{mg} \mathrm{L}^{-1}$; and dissolved oxygen 5.0-6.0 $\mathrm{mg} \mathrm{L}^{-1}$. The fish were fed twice a day with commercial pellets until satiety. After acclimation, fish samples were transferred to the experimental system where they were equally distributed into $250 \mathrm{~L}$ fiber tanks. The fish were kept undisturbed in such conditions for 7 days and feeding was discontinued 24 hours prior to the $50 \%$ lethal concentration tests $\left(96-\right.$ hour $\mathrm{LC}_{50}$ ), and sublethal exposures.

\section{Acute Toxicity: Lethal Concentration (96-hour $L C_{50}$ )}

Phenol 96-hour $\mathrm{LC}_{50}$ tests were performed under semistatic conditions with constant artificial aeration at stocking density of $1.0 \mathrm{~g} \mathrm{~L}^{-1}$ (IBAMA, 1987; OECD, 1992).

To determine the phenol toxicity to $I$. punctatus, 54 fish $(15.7 \pm 0.8 \mathrm{~g} ; 12.2 \pm 0.2 \mathrm{~cm})$ were randomly selected and equally distributed into six $250 \mathrm{~L}$ fiber tanks. The water flow was ceased and phenol was added into five tanks to obtain the nominal concentrations of 5,10,15, 20 and $30 \mathrm{~m} \mathrm{gL}^{-1}$. The sixth tank was kept with phenol-free water and was assigned as the control. Fish were not fed throughout the experiment period. The water was renewed every 24 hours and the phenol concentration was adjusted (see Supplementary Material for more detail). The semi-static exposure lasted 96 hours and the mortality was recorded every 24 hours. The water quality parameters (APHA, 1980) over the trials was kept at the following: temperature $27.0 \pm 1.0{ }^{\circ} \mathrm{C} ; \mathrm{pH} 6.9 \pm 0.3$; alkalinity $\left(\mathrm{HCO}_{3}^{-}\right) 54.0 \pm 2.0 \mathrm{mg} \mathrm{L}^{-1}$; hardness $\left(\mathrm{CaCO}_{3}\right) 31.0 \pm 3.0 \mathrm{mg}$ $\mathrm{L}^{-1}$; dissolved oxygen $6.0 \pm 0.5 \mathrm{mg} \mathrm{L}^{-1} ; \mathrm{NH}_{3}-\mathrm{NH}_{4}^{+} 0.20 \pm 0.02$ $\mathrm{mg} \mathrm{L}{ }^{-1}$; and $\mathrm{NO}_{2}^{-1} 0.07 \pm 0.01 \mathrm{mg} \mathrm{L}^{-1}$.

The acute toxicity of phenol to P. mesopotamicus was determined with 60 fish $(21.5 \pm 3.8 \mathrm{~g} ; 13.4 \pm 0.6 \mathrm{~cm})$. These fish were submitted to the same experimental procedure reported above for I. punctatus. The phenol was added to five tanks set up at concentrations of 5, 10, 25, 30 and $50 \mathrm{mg} \mathrm{L}^{-1}$. The sixth tank was kept with phenol-free water and assigned as control. The phenol concentrations were also adjusted every 24 hours (see Supplementary Material for more detail). The water quality parameters (APHA, 1980) over the trial was kept at the following: temperature $25.2 \pm 1.2{ }^{\circ} \mathrm{C} ; \mathrm{pH} 6.7 \pm 0.2$; alkalinity $\left(\mathrm{HCO}_{3}^{-}\right) 55.4 \pm 2.0 \mathrm{mg} \mathrm{L}^{-1}$; hardness $\left(\mathrm{CaCO}_{3}\right) 29.0 \pm$ $0.5 \mathrm{mg} \mathrm{L}^{-1}$; dissolved oxygen $5.2 \pm 1.1 \mathrm{mg} \mathrm{L}^{-1} ; \mathrm{NH}_{3}-\mathrm{NH}_{4}^{+} 0.48$ $\pm 0.05 \mathrm{mg} \mathrm{L}^{-1}$; and $\mathrm{NO}_{2}^{-1} 0.05 \pm 0.01 \mathrm{mg} \mathrm{L}^{-1}$.

\section{Sublethal exposure and hematological variables}

The sublethal exposure to phenol was carried out with 48 fish I. punctatus ( $43 \pm 10 \mathrm{~g} ; 16 \pm 1 \mathrm{~cm}$ ) exposed for 96 hours to $1.5 \mathrm{mg} \mathrm{L}^{-1}$ phenol $\left(10 \%\right.$ of $\left.\mathrm{LC}_{50}\right)$. The post-exposure recovery condition was undertaken immediately after exposure by placing the fish in phenol-free water for 7 days. Such sublethal experiment was conducted in 250L fiber tanks, following a random experimental design ( $n=12$ in each group: exposed and its respective control, post-exposure recovered and its respective control). The water was renewed every 24 hours and the phenol concentration was adjusted. The water quality 
parameters were maintained as reported above. The feeding was discontinued over the exposure and post-exposure recovery periods to prevent prandial metabolic alterations. The experiment was carried out in duplicates in a semi-static system. At the end of each experimental condition (exposure or post-exposure recovery), the fish were anesthetized in 40 $\mathrm{mg} \mathrm{L}^{-1}$ eugenol (Inoue et al., 2003) and blood samples were drawn from the caudal vein with heparinized syringes. The same protocol and experimental design was conducted to $P$. mesopotamicus, $(65 \pm 7 \mathrm{~g} ; 14.0 \pm 0.5 \mathrm{~cm})$ which were exposed to $3.3 \mathrm{mg} \mathrm{L}^{-1}$ of phenol $\left(10 \%\right.$ of 96 -hour $\left.\mathrm{LC}_{50}\right)$.

The hematocrit (Ht) level was determined by microhematocrit method in blood samples centrifuged at $13,400 \times g$ for $3 \mathrm{~min}$ in glass capillary microtubes. Total hemoglobin $(\mathrm{Hb})$ content was determined colorimetrically at 540nm (Drabkin, 1948). Red blood cells (RBC) were counted in a Neubauer chamber. The hematimetric indices, mean corpuscular volume (MCV), mean corpuscular hemoglobin $(\mathrm{MCH})$ and mean corpuscular hemoglobin concentration (MCHC) were calculated from the $\mathrm{Hb}$ content, $\mathrm{RBC}$ count and $\mathrm{Ht}$ values using standard formulae.

\section{Statistics}

The 96-hour $\mathrm{LC}_{50}$ of phenol to I. punctatus and to $P$. mesopotamicus were calculated with Trimmed SpearmanKarber $\mathrm{LC}_{50}$ Programs JSPEAR computer software (Hamilton et al., 1977). Significance was inferred at $P<0.05$. The hematological variables are expressed as mean \pm standard error (SE). Normal probability was assessed for each variable using the Kolmogorov-Smirnov test. Comparison of means for each variable was evaluated using Student t-test between the experimental groups and their respective control groups. The confidence limit level was $95 \%(P<0.05)$.

\section{RESULTS}

The phenol 96-hour $\mathrm{LC}_{50}$ to I. punctatus was $15.08 \mathrm{mg}$ $\mathrm{L}^{-1}$, and the inferior and superior limits were $12.67 \mathrm{mg} \mathrm{L}^{-1}$ and $17.96 \mathrm{mg} \mathrm{L}^{-1}$, respectively (Table 1 ). The fish mortality after exposure for 24 hours was observed at 15,20 and $30 \mathrm{mg} \mathrm{L}^{-1}$ of phenol concentrations. After 72 hours, fish mortality was at 10 and $15 \mathrm{mg} \mathrm{L}^{-1}$ of phenol. The fish did not present excessive mucus production, and no mucus was observed in the water.

Table 1 - Mortality of Ictalurus punctatus exposed to lethal concentration of phenol for 96 hours to determine 96 -hour $\mathrm{LC}_{50}$.

\begin{tabular}{lccc}
\hline Phenol $\left(\mathrm{mg} \mathrm{L}^{-1}\right)$ & Initial $n$ & Final $n$ & Mortality \% \\
\hline 0 & 9 & 9 & 0 \\
5 & 9 & 9 & 0 \\
10 & 9 & 8 & 11.11 \\
15 & 9 & 6 & 33.33 \\
20 & 9 & 1 & 88.88 \\
30 & 9 & 0 & 100 \\
\hline
\end{tabular}

The phenol 96-hour $\mathrm{LC}_{50}$ to $P$. mesopotamicus was 32.50 $\mathrm{mg} \mathrm{L}^{-1}$, and the inferior and the superior limits were 29.19 $\mathrm{mg} \mathrm{L}^{-1}$ and $36.34 \mathrm{mg} \mathrm{L}^{-1}$, respectively (Table 2 ). Fish mortality at the 24 hours from the exposure outset was observed at 30 $\mathrm{mg} \mathrm{L}^{-1}$ and $50 \mathrm{mg} \mathrm{L}^{-1}$ of phenol concentration. Fish exposed to all phenol concentrations exhibited hyperproduction of

Table 2 - Mortality of Piaractus mesopotamicus exposed to lethal concentration of phenol for 96 hours to determine 96-hour $\mathrm{LC}_{50}$.

\begin{tabular}{lccc}
\hline Phenol $\left(\mathrm{mg} \mathrm{L}^{-1}\right)$ & Initial $n$ & Final $n$ & Mortality \% \\
\hline 0 & 10 & 10 & 0 \\
5 & 10 & 10 & 0 \\
10 & 10 & 10 & 0 \\
25 & 10 & 10 & 0 \\
30 & 10 & 5 & 50 \\
50 & 10 & 0 & 100 \\
\hline
\end{tabular}

Table 3 - Hematological variables of Ictalurus punctatus after 96-hour sublethal exposure to phenol $\left(1.5 \mathrm{mg} \mathrm{L}^{1}\right)$ and post-exposure recovery period of 7 days.

\begin{tabular}{lcccc}
\hline $\begin{array}{l}\text { Blood } \\
\text { variable }\end{array}$ & \multicolumn{4}{c}{ Condition } \\
\hline $\mathrm{Ht}$ & Control & Exposure & Control & Recovery \\
$\mathrm{Hb}$ & $25 \pm 0.8$ & $25 \pm 0.6$ & $23 \pm 0.5$ & $22 \pm 0.7$ \\
$\mathrm{RBC}$ & $2.5 \pm 0.05$ & $2.5 \pm 0.05$ & $2.0 \pm 0.08$ & $2.6 \pm 0.05^{\mathrm{a}}$ \\
$\mathrm{MCV}$ & $104 \pm 4.4$ & $100 \pm 2.6$ & $114 \pm 2.7$ & $87 \pm 4.2^{\mathrm{a}}$ \\
$\mathrm{MCH}$ & $27 \pm 0.9$ & $28 \pm 0.9$ & $31 \pm 0.6$ & $23 \pm 0.6^{\mathrm{a}}$ \\
$\mathrm{MCHC}$ & $27 \pm 5.9$ & \pm 4.9 & $27 \pm 3.7$ & $27 \pm 4.1$ \\
\hline
\end{tabular}

Ht- hematocrit (\%); Hb-total hemoglobin $\left(\mathrm{g} \mathrm{dL}^{-1}\right)$; RBC- red blood cells counting $\left(10^{6}\right.$ cells $\left.\mathrm{mm}^{-3}\right)$; $\mathrm{MCV}$ (mean corpuscular volume $\left(\mu \mathrm{m}^{3}\right)$; $\mathrm{MCH}-$ mean corpuscular hemoglobin(pg cell-1 $)$; MCHC- mean corpuscular hemoglobin concentration $\left(\mathrm{g} \mathrm{dL}^{-1}\right)$. The values are followed by mean $\pm \mathrm{SE}$; ${ }^{\text {(a) }}$ significant difference between exposure/recovery and respective control group at $P<0.05(n=12)$.

Table 4 - Hematological variables of Piaractus mesopotamicus after 96-hour sublethal exposure to phenol $\left(3.3 \mathrm{mg} \mathrm{L}^{-1}\right)$ and after post-exposure recovery period of 7 days.

\begin{tabular}{lcccc}
\hline $\begin{array}{l}\text { Blood } \\
\text { variable }\end{array}$ & \multicolumn{4}{c}{ Condition } \\
\hline & Control & Exposure & Control & Recovery \\
$\mathrm{Ht}$ & $25 \pm 0.4$ & $31 \pm 0.6^{\mathrm{a}}$ & $26 \pm 0.3$ & $28 \pm 0.3$ \\
$\mathrm{Hb}$ & $7.3 \pm 0.1$ & $9.0 \pm 0,1^{\mathrm{a}}$ & $7.1 \pm 0.1$ & $8.1 \pm 0.1$ \\
$\mathrm{RBC}$ & $1.4 \pm 0.03$ & $1.8 \pm 0.03^{\mathrm{a}}$ & $1.5 \pm 0.04$ & $1.5 \pm 0.04$ \\
$\mathrm{MCV}$ & $173 \pm 5.0$ & $171 \pm 3.3$ & $162 \pm 4.3$ & $168 \pm 3.3$ \\
$\mathrm{MCH}$ & $50 \pm 0.8$ & $49 \pm 1.5$ & $46 \pm 1.3$ & $49 \pm 1.3$ \\
$\mathrm{MCHC}$ & $29 \pm 0.6$ & $29 \pm 0.3$ & $30 \pm 0.5$ & $29 \pm 0.5$ \\
\hline
\end{tabular}

Ht- hematocrit $(\%)$; Hb- total hemoglobin $\left(\mathrm{g} \mathrm{dL}^{-1}\right)$; RBC- red blood cells counting $\left(10^{6}\right.$ cells $\left.\mathrm{mm}^{-3}\right)$; MCV (mean corpuscular volume $\left(\mu \mathrm{m}^{3}\right)$; $\mathrm{MCH}-$ mean corpuscular hemoglobin (pg cell ${ }^{-1}$ ); MCHC- mean corpuscular hemoglobin concentration $\left(\mathrm{g} \mathrm{dL}^{-1}\right)$. The values are followed by mean $\pm \mathrm{SE}$; ${ }^{\text {(a) }}$ significant difference between exposure/recovery and respective control group at $P<0.05(n=12)$. 
mucus on the skin and gills. The mucus was evident in the water, which become cloudy, especially at the highest phenol concentrations.

The number of red blood cells (RBC) of I. punctatus increased at the end of recovery while the MCV and the $\mathrm{MCH}$ decreased significantly (Table 3 ). The $\mathrm{Ht}, \mathrm{Hb}$ concentration and RBC count of $P$. mesopotamicus increased at the end of exposure (Table 4). After post-exposure period in phenolfree water, hematological variables were achieved recovery in P. mesopotamicus.

\section{DISCUSSION}

According to Zucker (1985) classification, the values of phenol $\mathrm{LC}_{50}$ in this present study ranged from 10 to $100 \mathrm{mg} \mathrm{L}^{-1}$, which is considered slightly toxic chemical to I. punctatus and $P$. mesopotamicus. The 96-hour CL50 for both species was within the $\mathrm{LC}_{50}$ range reported for several fish species (Table 5). The phenol $\mathrm{LC}_{50}$ value of I. punctatus is inferior to those reported for other catfishes (Siluriformes), such as Saccobranchus fossilis and Clarias gariepinus (Changon \& Hlahowskyj, 1989; Ibrahem, 2012). However, phenol 96-hour CL50 for $P$. mesopotamicus was higher than that reported for $B$. amazonicus (another Characiforme species) (Hori et al., 2006). Differences in the fish life stage, body size, water physicochemical parameters, the absorption rate and detoxification mechanisms among species can create differences in $\mathrm{LC}_{50}$ obtained from bioassays of acute toxicology tests (Bucher \& Hofer, 1993; Rand et al., 1995; Saha et al., 1999).

Mucus secretion in the gills and skin in P. mesopotamicus was likely a protective mechanism to cope with phenol

Table 5 - Phenol acute toxicity of several fish species exposed for 96 hours

\begin{tabular}{lc}
\hline Fish species & LC $_{\mathbf{5 0}}$; 96 hours \\
\hline Notopterus notopterus $^{1}$ & 12.53 \\
Ictalurus punctatus $^{2}$ & 15.08 \\
Brycon amazonicus $^{3}$ & 17.40 \\
Oreochromis niloticus $^{4}$ & 28.00 \\
Oreochromis mossambicus $^{5}$ & 28.49 \\
Oreochromis aureus $^{6}$ & 29.00 \\
Colisa fasciatus $^{7}$ & 32.70 \\
Piaractus mesopotamicus $^{2}$ & 32.50 \\
Oreochromis mossambicus $^{8}$ & 35.00 \\
Clarias gariepinus $^{9}$ & 35.00 \\
Saccobranchus fossilis $^{10}$ & 39.40 \\
Lebistes reticulatus $^{11}$ & 47.50 \\
\hline
\end{tabular}

${ }^{1}$ Verma et al., $1981 ;{ }^{2}$ present study; ${ }^{3}$ Hori et al., 2006; ${ }^{4} \mathrm{Gad}$ \& Saad, 2008; ${ }^{5}$ Saha et al., 1999, ${ }^{6} \mathrm{Abdel}-\mathrm{Hameid}, 2007 ;{ }^{7}$ Verma et al., 1980; ${ }^{8}$ Sannadurgappa, 2007; ${ }^{9}$ Ibrahem, 2012; ${ }^{10}$ Changon \& Hlahowskyj, 1989; ${ }^{11}$ Gupta et al., 1982 exposure, as was earlier proposed to be occurring in Clarias gariepinus exposed to phenol (Ibrahem, 2012). The difference in $\mathrm{LC}_{50}$ between $P$. mesopotamicus and I. punctatus can be due to the physical barrier caused by mucus. However, other approaches are needed to understand this matter.

Although phenol was slightly toxic to I. punctatus and to P. mesopotamicus (Zucker, 1985), sublethal exposure to phenol can provoke several injuries to fish, such as metabolic alterations (Hori et al., 2006; Sanadurgappa et al., 2007), bioaccumulation (Sanadurgappa et al., 2007), genotoxicity (Gad \& Saad, 2008), impairment of maturity and fecundity (Saha et al., 1999), and an increase of the classical stress responses (Hori et al., 2008).

The RBC of I. punctatus was kept constant over the exposure to phenol, suggesting that a branchial damage was likely not enough to impair oxygen exchange. However, an increase of RBC was observed after recovery period. This hematological alteration was likely due to increase in metabolic demand. The increase of RBC followed by a reduction in $\mathrm{MCV}$ and $\mathrm{MCH}$ was likely consequence of increased erythropoiesis. The reduced values of MCV and $\mathrm{MCH}$ observed in the recovered fish could be the result of circulating young erythrocytes, which are smaller cells and can be present in the peripheral blood of fish exposed to environmental stressors (Clauss et al., 2008). Stress is caused in Heteropneustes fossilis by long-term exposure to deltamethrin (Kumar et al., 1999) and in Cyprinus carpio L. exposed to terbuthryn (Velisek et al., 2010), which result in similar hematological alterations.

Hematological changes after sublethal exposure to phenol suggested respiratory distress in $P$. mesopotamicus, which have been reported in B. amazonicus exposed to phenol for 96 hours (Avilez et al., 2008). RBC count might have increased due to spleen contraction or erythropoiesis in order to absorb and provide oxygen to tissues. This could be related to the excessive mucus observed in the acute toxicology test. Mucus is often secreted by fish to minimize irritant toxic effect and prevent the penetration of chemical toxicant(Verma et al., 1980; Pickering \& Pottinger, 1995; Kan et al., 2012). Proliferation of mucous cells and chloride cells, mucus secretion and gill hypertrophy are typical defense mechanisms that increase the pollutant-blood diffusion distance, causing impaired gaseous exchange (Kan et al., 2012). Salmo gairdnerii (Mitrovic et al., 1968) and Cotus gobio (Bucher \& Hofer, 1993) fish species have been reported to produce excessive mucus when exposed to phenol. Mucus profusion is accompanied by acute respiratory distress in Oreochromis mossambicus (Saha et $a l ., 1999)$ and respiratory insufficiency in Clarias gariepinus (Ibrahem, 2012) when exposed to phenol.

In conclusion, phenol contaminated water is associated with many physiological changes of aquatic organisms, such as fish, therefore deserving the attention regarding the ecological consequences and impact. Even slight toxicity level of phenol during the acute toxicity tests in this study suggested that phenol can be harmful, and that the 
damages can extend into the recovery period, as observed in I. punctatus species. The present data has evaluated the potential damage caused by phenol in aquatic environments, particularly at sublethal conditions.

\section{ACKNOWLEDGEMENTS}

The authors are thankful to the colleagues of the Laboratory of Adaptive Biochemistry in the Department of Genetic and Evolution for their technical support. In particular, we are thankful to Mr. Antônio Donizete Aparecido da Silva and Dr. Claudinei da Cruz for technical support, and Ikdip Brar for English revision. We are also obliged to CNPq (National Council for Scientific and Technological Development) and Capes (Coordenação de Aperfeiçoamento de Pessoal de Nível Superior) for the financial support.

\section{REFERENCES}

ABDEL-HAMEID, N.A.H. 2007. Physiological and histopathological alterations induced by phenol exposure in Oreochromis aureus juveniles. Turk. J. Fish.Aquat. Sci., 7: 131-138.

APHA (American Public Health Association). 1980. Standard methods for examination of water and wastes. 12 ed.Washington, DC: Join editorial board.

AVILEZ I.M., HORI T.S.F., ALMEIDA L.C., HACKBARTH A., BASTOS NETO J.C., BASTOS V.L.F.C.\& MORAES G. 2008. Effects of phenol in antioxidant metabolism in matrinxã, Brycon amazonicus (Teleostei; Characidae). Comp. Biochem. Physiol. C 148,136:142. http://dx.doi.org/10.1016/j.cbpc.2008.04.008

BOLOGNESI, C., PERRONE, E., ROGGIERI, P., PAMPANIN, D.M. \&SCIUTTO, A. 2006. Assessment of micronuclei induction in peripheral erythrocytes of fish to xenobiotics under controlled conditions. Aquat. Toxicol. 78: 93-98. http://dx.doi. org/10.1016/j.aquatox.2006.02.015

BRASIL. Ministério do Meio Ambiente. Conselho Nacional do Meio Ambiente - CONAMA. Portaria n. 357, de 17 de março 2005. Diário Oficial [da] República Federativa do Brasil. Poder Executivo, Brasília, DF, 2005.

BUCHER, F.\& HOFER, R. 1993.Histopathological effects of sublethal exposure to phenol on two variously pre-stressed populations of bullhead (Cottus gobioL.). Environ. Contam. Toxicol., 51: 309-316. http://dx.doi.org/10.1007/BF00198897

CETESB, Companhia Ambiental do Estado de São Paulo (São Paulo), 2008. Relatório de qualidade das águas interiores do estado de São Paulo 2007 / CETESB, São Paulo: CETESB. 537p.

CETESB, Companhia ambiental do Estado de São Paulo, 2014. Águas superficiais, Variáveis de qualidade de água. Acessed 06/04/14. http://www.cetesb.sp.gov.br/agua/aguas-superficiais/34variaveis-de-qualidade-das-aguas---old

CHANGON, N.\&HLAHOWSKYJ, I.1989. Effects of phenol exposure on the thermal tolerance ability of the central stoneroller minnow. Environ. Contam. Toxicol., 42: 614-619. http://dx.doi. org/10.1007/BF01700246

CLAUSS T.M., DOVE A.D.M.\& ARNOLD J.E.2008. Hematologic disorders of fish. Vet.Clin.Exot. Anim.11: 445-462. http:// dx.doi.org/10.1016/j.cvex.2008.03.007

DRABKIN D.L.,1948.The standardization of hemoglobin measurement. Am. J. Med. Sci. 215: 110-111.

GAD, N.S.\&SAAD, A.S. 2008. Effect of environmental pollution by phenol on some physiological parameters of
Oreochromisniloticus. Global Veterinaria, 2: 312-319.

GUPTA, P.K., MUJUMDAR, V.S., RAO, P.S.\&DURVE, V.S.1982. Toxicity of Phenol, Pentachlorophenol and Sodium Pentachlorophenolate to a Freshwater Teleost Lebistesreticulatus (Peters). Acta hydrochimica et hydrobiologica 10(2): 177-181. http://dx.doi.org/10.1002/aheh.19820100207

HAMILTON, M.A. RUSSO, R.C.\& THURSTON, V. 1977. Trimed Spearman-Karbermethod for estimatingmediallethal concentrations in toxicitybioassays. Environ. Sci. Technol., 7 : 714-719. http://dx.doi.org/10.1021/es60130a004

HORI T.S.F., AVILEZ I.M., INOUE L.K. \& MORAES G. 2006. Metabolical changes induced by chronic phenol exposure in matrinxã Brycon amazonicus (teleostei: characidae) juveniles. Comp. Biochem. Physiol. C, 143:67-2.http://dx.doi. org/10.1016/j.cbpc.2005.12.004

HORI, T.S.F., AVILEZ, I.M., IWAMA, G.K., JOHNSON, S.C., MORAES, G. \&AFONSO, L.O.B.2008. Impairment of the stress response in matrinxã juveniles (Brycon amazonicus) exposed to low concentrations of phenol. Comp. Biochem. Physiol. C, 174: 416-423. http://dx.doi.org/10.1016/j.cbpc.2008.01.003

IBAMA (InstitutoBrasileiro do MeioAmbiente e dos RecursosNaturaisRenováveis). 1987. Avaliação da toxicidadeaguda para peixes. Manual de testes para avaliação de ecotoxicidade de agentes químicos. Parte D. 3. Brasília, DF.

IBRAHEM, M.D. 2012. Experimental exposure of African catfish Clarias gariepinus (Burchell, 1822) to phenol: Clinical evaluation, tissue alterations and residue assessment. J. Advance. Res., 3(2): 177-183.http://dx.doi.org/10.1016/j.jare.2011.07.002

KAN, Y., CENGIZ, E.I., UGURLU, P.\&YANAR, M. 2012. The protective role of vitamin $\mathrm{E}$ on gill and liver tissue histopathology and micronucleus frequencies in peripheral erythrocytes of Oreochromis niloticus exposed to deltamethrin. Environ. Toxicol Phar., 34:170-179. http://dx.doi.org/10.1016/j.etap.2012.03.009

KLEINOW, K.M., NICHOLS, J.W., HAYTON, W.L., MCKIM, J.M. \& BARROM, M.G. 2008. Toxicokinetics in Fishes. In: Di Giulio, R.T., Hinton D.E. (eds), The Toxicology of fishes. Boca Raton, FL: CRC Press, Taylor and Francis Group, pp. 55-152.

KUMAR S., LATA S. \& GOPAL K. 1999. Deltamethrin induced physiological changes in freshwater catfish Heteropneustes fossilis. Bull. Environ. Contam. Toxicol.62: 254-258. http:// dx.doi.org/10.1007/s001289900867

KUMAR, V.\& MUKHERJEE, D. 1988. Phenol and sulfide induced changes in the ovary and liver of sexually maturing common carp, Cyprinuscarpio.Aquat. Toxicol., 13,53-59. http://dx.doi. org/10.1016/0166-445X(88)90072-0

LEE, Y.G., HWANG, S.H. \&KIM, S.D. 2006. Predicting the toxicity of substituted phenols to aquatic species and its changes in the stream and effluents waters. Arch. Environ. Contam. 50: 213219. http://dx.dois.org/10.1007/s00244-004-1259-6

LOOMIS,W.F., LIPMANN, F., 1948. Reversible inhibition of the coupling between phosphorylation and oxidation. J. Biol. Chem. 173, 807-814.

MICHALOWICZ, J. \& DUDA, W.2007. Phenols - Source and toxicity. Pol. J. Environ. Stud., 16(3): 347-362.

MITROVIC, V.V., BROWN, V.M., SHURBEN, D.G. \& BERRYMAN, M.H. 1968. Some pathological effects of subacute and acute poisoning of rainbow trout by phenol in hard water. Water Res., 2: 249-254. http://dx.doi.org/10.1016/00431354(68)90017-1

OECD (Guideline for testing of chemicals). 1992. Fish, Acute Toxicity Test, 9p.

PICKERING, A.D. \& POTTINGER, T.G. 1995. Biochemical effects of stress. In: Hochachka ; Mommsen (eds.), Biochemistry and molecular biology of fishes, vol.5. Amsterdam: Elsevier 
Science B. V. pp. 349-379.

RAND, G.M., WELLS, P.G. \& MCCARTY, L.S.1995. Introduction to aquatictoxicology. In : Rand, G.M. (ed), Fundamentals of aquatic toxicology, 2nd edition. Boca Raton, FL : CRC Press, pp. 3-66.

RAVICHANDRAN S. \& ANANTHARAJ B. 1984. Effect of phenol on the phosphomonoesterases and ATPase activity in the fish Sarotherodon mossambicus (Peters) in saline waters. Proc. Indian. Acad. Sci. 93(6): 557-563. http://dx.doi.org/10.1007/ BF03186305

ROCHE H. \& BOGÉ G. 2000. In vivo effects of phenolic compounds on blood parameters of a marine fish (Dicentrarchuslabrax). Comp. Biochem. Physiol. C 125: 345-353.

SAHA N.C., BHUNIA F. \& KAVIRAJ A. 1999. Toxicity of phenol to fish and aquatic ecosystems. Bull. Environ. Contam. Toxicol. 63:195-202. http://dx.doi.org/10.1007/s001289900966

SANNADURGAPPA, D., RAVINDRANATH, N.H. \& ALADAKATTI, R.H.2007. Toxicity, bioaccumulation and metabolism of phenol in the freshwater fish. J. Basic Clin. Physiol. Pharmacol., 18: 65-77.

TSUTSUI T., HAYASHIN., MAIZUMI H., HUFF J. \& BARRET J.C. 1997. Benzene-, catechol-, hydroquinone- and phenol-induced cell transformation, gene mutations, chromosome aberrations,

Phenol concentration in acute toxicity test of Piaractus mesopotamicus

\begin{tabular}{lcccccc}
\hline Period & \multicolumn{7}{c}{ Phenol $\mathrm{mg} \mathrm{L}^{-1}$} \\
\hline & 0 & 5 & 10 & 25 & 30 & 50 \\
$0 \mathrm{~h}$ & 0 & 0 & 0 & 0 & 0 & 0 \\
$0 \mathrm{~h}$, & 0 & 5.20 & 10.5 & 25.9 & 30.5 & 52.2 \\
$24 \mathrm{~h}$ & 0 & 3.50 & 9.50 & 23.8 & 28.4 & 51.9 \\
$24 \mathrm{~h}$, & 0 & 5.55 & 11.2 & 25.5 & 30.5 & $\#$ \\
$48 \mathrm{~h}$ & 0 & 0.05 & 0.02 & 0.04 & 0.02 & $\#$ \\
$48 \mathrm{~h}$, & 0 & 5.20 & 10.55 & 26.1 & 30.9 & $\#$ \\
$72 \mathrm{~h}$ & 0 & 0.02 & 0.05 & 0.04 & 0.08 & $\#$ \\
$72 \mathrm{~h}$, & 0 & 5.7 & 10.6 & 25.8 & 31.2 & $\#$ \\
$96 \mathrm{~h}$ & 0 & 0.02 & 0.04 & 0.05 & 0.09 & $\#$ \\
\hline
\end{tabular}

The phenol concentration was determined in each concentration of the test along 96 hours. $0 \mathrm{~h}=$ prior to the experiment (without phenol); $0 \mathrm{~h}$ ' = start of the experiment (with phenol); ( $24 \mathrm{~h}, 48 \mathrm{~h}, 72 \mathrm{~h}$ and $96 \mathrm{~h})=$ the phenol concentration before renewing the water; ( 24 h', 48 h' and 72 h') = the adjusted phenol concentration after renewing the water; \# not available data. aneuploidy, sister chromatid exchanges and unscheduled DNA synthesis in Syrian hamster embryo cells. Mutat. Res., 373:113123. http://dx.doi.org/10.1016/S0027-5107(96)00196-0

VELISEK J., SUDOVA E., MACHOVA J. \&SVOBODOVA Z. 2010. Effects of sub-chronic exposure to terbutryn in common carp (Cyprinus carpio L.). Ecotoxicol. Environ. Saf. 73: 384390. http://dx.doi.org/10.1016/j.ecoenv.2009.10.005

VERMA S.R., RANI, S. \& DALELA, R.C. 1981. Synergism, antagonism, and additivity of phenol, pentachlorophenol, and dinitrophenol to a fish (Notopterus notopterus). Arch. Environ. Contam. Toxicol. 10: 365-370.

VERMA S.R., RANI, S., TYAGI, A.K. \&DALELA, R.C. 1980 Evaluation of acute toxicity of phenol and its chloro- and nitroderivates to certain teleosts. Wat. Air Soil Pollut. 14: 95-102. http://dx.doi.org/10.1007/BF00291828

YIN D., GU Y., LI Y., WANG X. \& ZHAO Q. 2006. Pentachlorophenol treatment in vivo elevates point mutation rate in zebrafish p53 gene. Mut. Res. 609(1): 92-101. http://dx.doi. org/10.1016/j.mrgentox.2006.06.025

ZAGATTO, P.A. \& BERTOLETTI, E.2006. Ecotoxicologia aquática, princípios e aplicações. São Carlos: Rima, 478p.

ZUCKER, E.1985. Hazard evaluation division, Standard evaluation procedure. Acute toxicity test for freshwater fish. USEPA publication 540/9-85-006, 17p.

Phenol concentration in the acute toxicity test of Ictalurus punctatus

\begin{tabular}{lcccccc}
\hline Period & \multicolumn{7}{c}{ Phenol $\mathrm{mg} \mathrm{L}^{-1}$} \\
\hline & 0 & 5 & 10 & 15 & 20 & 30 \\
$0 \mathrm{~h}$ & 0 & 0 & 0 & 0 & 0 & 0 \\
$0 \mathrm{~h}$, & 0 & 5.65 & 10.8 & 15.8 & 20.8 & 30.5 \\
$24 \mathrm{~h}$ & 0 & 2.77 & 10.7 & 14.1 & 20.7 & 30.2 \\
$24 \mathrm{~h}$, & 0 & 5.88 & 11.2 & 15.9 & 24.4 & $\#$ \\
$48 \mathrm{~h}$ & 0 & 0.06 & 0.07 & 0.15 & 0.13 & $\#$ \\
$48 \mathrm{~h}$, & 0 & 5.48 & 11.0 & 15.9 & 20.6 & $\#$ \\
$72 \mathrm{~h}$ & 0 & 0.03 & 0.04 & 0.07 & 0.11 & $\#$ \\
$72 \mathrm{~h}$, & 0 & 5.45 & 10.8 & 15.1 & 20.9 & $\#$ \\
$96 \mathrm{~h}$ & 0 & 0.03 & 0.04 & 0.09 & 0.07 & $\#$ \\
\hline
\end{tabular}

The phenol concentration was determined in each concentration of the test along 96 hours: $0 \mathrm{~h}=$ prior to the experiment (without phenol); $0 \mathrm{~h}$ ' = start of the experiment (with phenol); $(24 \mathrm{~h}, 48 \mathrm{~h}, 72 \mathrm{~h}$ and $96 \mathrm{~h})=$ phenol concentrations before renewing the water; $\left(24 h^{\prime}, 48\right.$ ' and $\left.72 h^{\prime}\right)=$ adjusted phenol concentrations after water renewing ;\# not available data. 